\title{
Laterality and general intelligence in children aged 6 - 8 years
}

\author{
Nada ARSENI ${ }^{1}$, Iacob HANȚIU²
}

\begin{abstract}
Aim: The aim of this study was to identify and analyze the types of laterality and level of general intelligence in primary school children, aged six to eight years. Methods: The sample consisted of 120 students, both boys and girls. General intelligence was measured using Raven's Coloured Progressive Matrices (CPM), while laterality was assessed using the Harris Test for lateral dominance. Results: The results obtained highlight that the dominant type of laterality is RRR - completely right-handed with stably accomplished laterality (81 subjects), followed by RLR - crossed ocular-manual and stably accomplished laterality (29 subjects). The proportion of those with LLL laterality - completely left-handed with stably accomplished laterality is small ( 4 subjects). In terms of general intelligence, most participants had IQs that can be classified in the category of those with a higher level of intelligence ( 65 subjects), succeeded by those with a superior medium level (27 subjects). Conclusion: Identifying the type of laterality and level of intelligence of children participating in physical education and sports classes is needed in order to leverage the intervention on the psychomotor components and to facilitate the process of adaptation of the child to the school environment.
\end{abstract}

Key words: general intelligence, QI, laterality, Raven's Colored Progressive Matrices, Harris test for lateral dominance, children

\section{Rezumat}

Scop: Scopul cercetării a fost de a identifica și a analiza tipurile de lateralitate și nivelul inteligenţei generale la elevii din ciclul primar, cu vârste cuprinse între 6 şi 8 ani. Metode: Eşantionul studiat a inclus 120 de elevi, atât fete, cât şi băieți. Nivelul inteligenței generale a fost măsurat folosind Matricile Progresive Raven Color (MPC Raven), iar tipul de lateralita te a fost determinat utilizând Proba de lateralitate Harris. Rezultate: Rezultatele obținute evidențiază că tipul de lateralitate dominant este DDD - dreptaci complet cu lateralitate stabil definitivată (81 subiecți), urmat de DSD - lateralitate ocular-manuală încrucișată și stabil definitivată (29 subiecți). Ponderea celor cu lateralitate SSS - stângaci complet cu lateralitate stabil definitivată este mică (4 subiecți). În ceea ce privește inteligența generală majoritatea participanților au înregistrat IQ-uri încadrabile în categoria celor cu un nivel superior de inteligență (65 subiecți), succedat de categoria celor cu un nivel mediu superior (27 subiecți). Concluzii: Identificarea tipului de lateralitate și al nivelului de inteligență al copiilor participanți la orele de educație fizică și sport este impetuos necesară în vederea eficentizării intervenției asupra componentelor psihomotricității și asupra facilitării procesului de adaptare al copilului la mediul școlar.

Cuvinte cheie: inteligenţa generală, IQ, lateralitate, Matricile Progresive Raven Color, Proba de lateralitate Harris, copii

\footnotetext{
${ }^{1}$ Assistant Professor, PhD student, University of Babeș-Bolyai, Cluj-Napoca, Romania, Faculty of Physical Education and Sports, $e$-mail: arseni.nada@e-uvt.ro

${ }^{2}$ Professor, PhD, University of Babeș-Bolyai, Cluj-Napoca, Romania, Faculty of Physical Education and Sports, Romania
} 


\section{Introduction}

Capturing information from the external environment and performing certain acts in the form of appropriate responses is possible in children due to psychomotor education, which ensures the premises for their harmonious development.

Psychomotricity involves the participation of mental processes and functions, which facilitate the adaptation of the individual to the environment from several points of view: pragmatic, social, aesthetic and educational adaptation [1].

At the same time, psychomotricity highlights the links between motor skills, intellectual development and affectivity, contributing to the detailed assessment of children [2].

When addressing the issue of psychomotricity, the components identified by L. Picq and P. Vayer, classified in the following categories, should not be omitted: basic motor behaviours (oculomotor coordination, balance, general dynamic coordination); neuromotor behaviours (muscle tone and proprioceptive sensations); perceptualmotor behaviours and structures (corporal scheme, laterality, spatial-temporal orientation) [3]; the last category plays an important role in the child's adaptation to the school environment. Laterality is a component of perceptual-motor behaviors and structures that influences the learning process and the success of motor acts.

Its approach requires differentiating it from the concept of lateralization. Lateralization is the tendency of one of the cerebral hemispheres to be dominant and specialized in various functions or processes, which determines the preference for the use of one of the two parts of the body for the performance of tasks [4], while laterality refers to the structure and function of the paired organs or two similarly arranged areas of the unpaired organs, distributed on the right and left sides, the specific functions being represented differently in the two hemispheres of the brain [5]. The type of laterality of the individual can be identified by establishing manual, ocular, podal and auditory dominance; the laterality formula being classified in categories: right-handed, left-handed, crosssided or unspecified [6]. Around the age of four, children begin the process of finalizing laterality, by organizing and distributing the cognitive and sensorimotor functions; afterwards,in the interval between six and seven years there will be a stabilization of laterality, and between ten and twelve the consolidation of the type of laterality [7]. Regarding the asymmetry of the cerebral hemispheres, it was found that in most people, the left hemisphere is superior to the right in terms of language functions, being specialized in the processing of information of a predominantly analytical, linear, serial and temporal nature, and the right hemisphere is superior for visuo-spatial functions, processing synthetic, configurational, simultaneous and holistic information [8]. In the school environment, the brain dominance plays a major role, as it dictates how students approach, memorize and process various information, determining their learning and thinking style. Thinking is the most effective and natural way of processing information, which can be linear when the dominant cerebral hemisphere is the left one (learning process involving progressive task performance and characteristic of disciplines such as mathematics) or global, when the right hemisphere is dominant - subjects being more comfortable with processing new information that they can integrate into an overall picture without going through linear steps or tasks [9].

As a superior process of knowledge, thinking is also closely related to general intelligence, the two concepts being used over time side by side, thinking being included in the sphere of intelligence [10]. Intelligence is the ability of the person to adapt to the environment by identifying the relationships between various objects or phenomena and finding the right solutions to solve the requirements of new situations. [11]. By supporting memory and complementing it, intelligence influences and determines school success [10]. In 1956, Piaget stated that "all cognitive mechanisms depend on movement; in addition to language and conceptualization, knowledge primarily involves an action on an object and therefore its roots require a permanent representation of movement at the highest levels of the brain" [12]. Interest in the association between physical activity and cognitive skills in school-age children is very high, given the results of studies 
supporting the positive impact that the usual practice of exercise and sports has on the development of cognition $[13,14,15,16]$; higher significant performance was recorded for primary school children in mathematics and in reading, when physical activity is carried out systematically [17].

In the case of children with instrumental disorders of writing and reading, problems related to spatial orientation, motor clumsiness, poorly developed body scheme, indecision in the use of both parts of the body for the performance of tasks have been identified; these difficulties are indicators of problems in the area of laterality and it is necessary for primary school teachers to identify and analyse these issues in order to correct them through an efficient teaching process, adapted to the specific needs of pupils [4].

Given that motor exercises stimulate, act and synergize the functions and activity of the nervous, circulatory, muscular, lymph-ganglionary and osteoarticular system, and psychomotricity is an imperative in the psychological and somatic adaptation of children [18], it is necessary to study the type and frequency of manifestation of general laterality and intelligence, in order to identify physical exercises aimed at contributing to the harmonious development of subjects, beneficial both in school activity and in their daily life.

\section{The purpose of this research}

One of the main objectives of physical school education is to ensure the correct growth and physical development of the younger generation. It is for this reason that we believe that it is necessary to know the level of general intelligence of children, to assess, prevent and treat laterality disorders, which must be permanently in the attention of physical education and sports teachers. Only in this way they will be able to choose the appropriate means to achieve this objective. Taking into account the above, we can say that the purpose of the research was to identify and analyse the dominant laterality types and the level of general intelligence of subjects aged six, seven and eight years who participate in physical education and sports classes.

Hypothesis
The dominant laterality type and level of general intelligence manifest differently in 6-8 year olds participating in physical education and sports classes.

\section{Material and Methods}

This research is a non-experimental and descriptive study.

The research took place between 6 November 2017 and 5 May 2018 in Reşiţa, at the School with grades I-VIII No. 1, at the National College "DiaconoviciTietz" and at "Mihai Peia" Middle School. The study involved 120 subjects, aged 6 to 8 years, both girls and boys.

Following the consent of the institutions involved in the investigation and of the legal guardians of the subjects, the data was collected and analysed.

The demographic data of the subjects were collected through a questionnaire. The data obtained by completing it, indicates that 66 subjects were girls (55\%) and 54 boys (45\%); $91.66 \%$ come from urban areas $(\mathrm{N}=110)$, and $8.34 \%$ are from rural areas $(\mathrm{N}=10)$. Subjects were divided by age into the following three groups:

- Group 1 - subjects aged 6 years $(\mathrm{N}=29$ representing 24,17\%);

- Group 2 - subjects aged 7 years $(\mathrm{N}=58$ representing $48.33 \%$ );

- Group 3 - subjects aged 8 years $(\mathrm{N}=33$ representing $27.50 \%$ ).

The laterality-type of the subjects in the studied sample was assessed using the Harris Laterality Test, which aims to establish lateral dominance on the eye-hand-foot coordinates [19]. The level of general intelligence was measured with the Raven Color Progressive Matrices -MPC Raven [20].

The results obtained after applying the tests were recorded and analysed with Microsoft Excel®.

\section{Results}

It was found out, after the application of the Harris Laterality Test (Figure 1), that from the whole group studied $(\mathrm{N}=120), 81$ subjects were completely right-handed with stably accomplished laterality - RRR (67.50\%); 29 had crossed ocularmanual and stably accomplished laterality - RLR (24.16\%); 4 were completely left-handed with stably accomplished laterality - LLL (3.33\%); 4 had 
homogeneous ocular-manual and stably accomplished laterality - RRL (3.33\%); 1 had crossed ocular-manual and stably accomplished laterality - LRR (0.83\%); and 1 was with homogeneous ocular-manual and stably accomplished laterality - LLR (0.83\%).

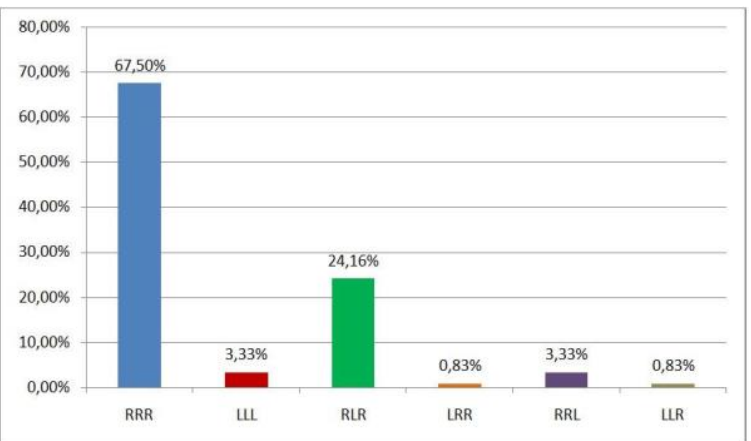

Figure 1. Type of laterality of the subjects included in the study $(\mathrm{N}=120)$

Caption- RRR - completely right-handed with stably accomplished laterality, LLL - completely left-handed with stably accomplished laterality, RLR - crossed ocular-manual and stably accomplished laterality, LRR - crossed ocular-manual and stably accomplished laterality, RRL - homogeneous ocularmanual and stably accomplished laterality, LLR - homogeneous ocular-manual and stably accomplished laterality

Regarding the level of general intelligence of the subjects, measured with CPM Raven, it was found that 65 of them had superior intelligence $(54.17 \%)$, 21 were with intelligence above the average level (17.50\%), 27 had average superior intelligence $(22.5 \%)$ and 7 were with average inferior intelligence (5.83\%). The results for the whole group are shown in Figure 2:



Figure 2. Level of general intelligence of the subjects included in the study $(\mathrm{N}=120)$

Analysis by age group
In the 6-year group $(\mathrm{N}=29)$, there are 22 completely right-handed subjects with stably accomplished laterality - RRR (75.86\%), 1 subject completely left-handed with stably accomplished laterality - LLL (3.44\%), 5 subjects were with crossed ocular-manual and stably accomplished laterality - RLR (17.24\%), and 1 subject was with crossed ocular-manual and stably accomplished laterality - LRR (3.44\%). The results are presented in Figure 3.

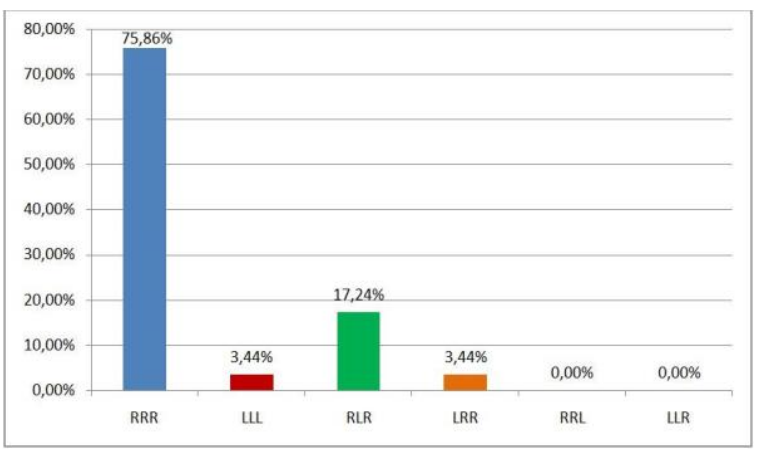

Figure 3. Type of laterality in the 6-year group $(\mathrm{N}=29)$

In the group of 7-year-old subjects (Figure 4) there were 38 completely right-handed subjects with stably accomplished laterality - RRR (65.51\%), 1 subject completely left-handed with stably accomplished laterality - LLL (1.71\%), 16 with crossed ocular-manual and stably accomplished laterality - RLR (27.58\%), and 3 with homogeneous ocular-manual and stably accomplished laterality RRL (5.17\%).

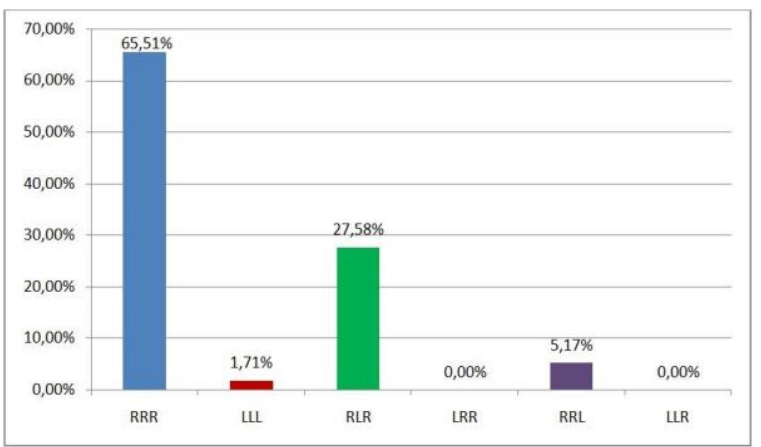

Figure 4. Type of laterality in the 7-year group $(\mathrm{N}=58)$

The types of laterality of the last group - that of subjects aged 8 years are highlighted in Figure 5. It was found that 21 of them were completely righthanded with stably accomplished laterality - RRR 
(63.63\%), 2 were completely left-handed with stably accomplished laterality - LLL (6.06\%), 8 subjects had crossed ocular-manual and stably accomplished laterality - RLR (24.24\%), 1 subject had homogeneous ocular-manual and stably accomplished laterality - RRL (3.03\%), and 1 subject had crossed ocular-manual and stably accomplished laterality - LRR (3.03\%).

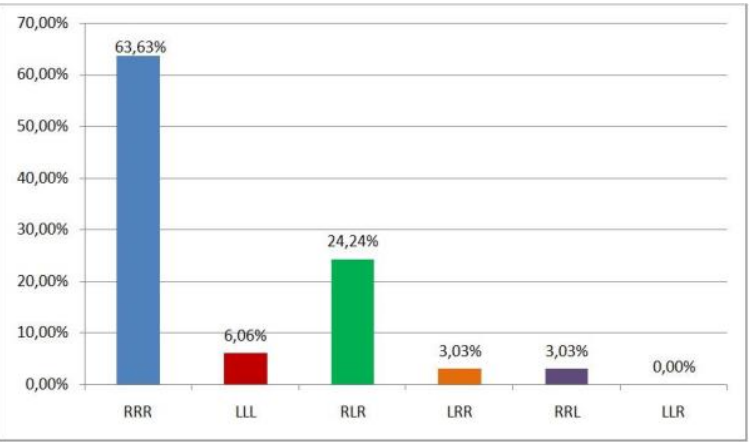

Figure 5. Type of laterality in the 8-year group $(\mathrm{N}=33)$

The general intelligence level of the 6-year-old subjects is shown in Figure 6. It can be seen that 20 of them have a superior level of intelligence (68.96\%), 4 are with general intelligence above the average level (13.79\%), and 5 are with average superior general intelligence (17.24\%).

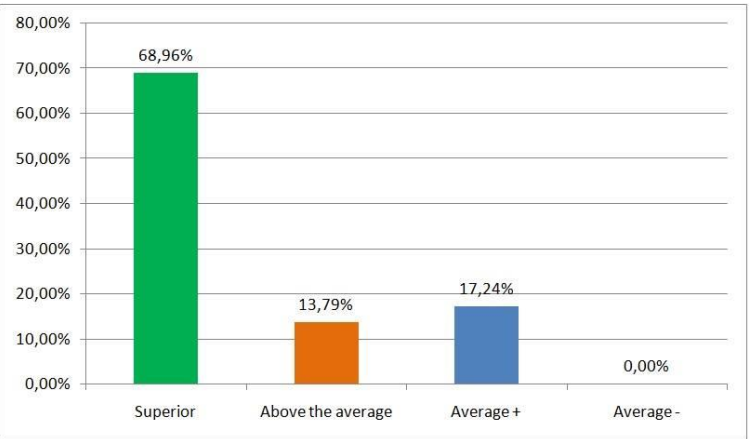

Figure 6. Level of general intelligence in the 6-year group $(\mathrm{N}=29)$

In the group of subjects aged 7 years (Figure 7), 26 had superior intelligence (44.83\%), 13 had above average intelligence $(22.41 \%), 14$ subjects had average superior intelligence $(24.13 \%)$, and 5 had average inferior intelligence (8.62\%).

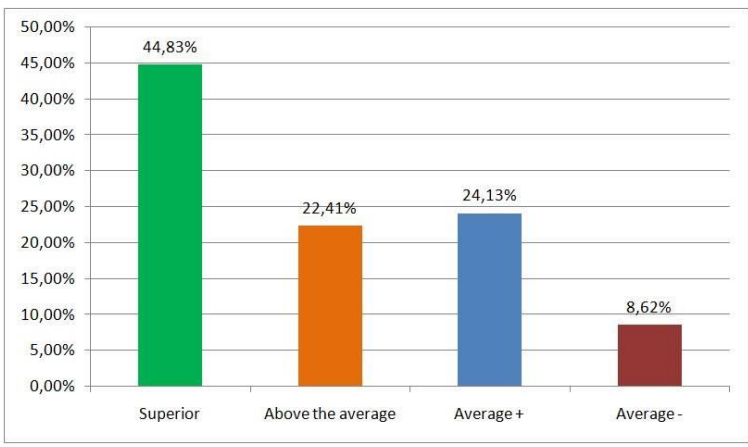

Figure 7. Level of general intelligence in the 7-year group $(\mathrm{N}=58)$

In the 8-year group (Figure 8), 19 subjects had a superior level of general intelligence (57.58\%), 4 had general intelligence above the average level $(12.12 \%), 8$ were with average superior intelligence (24.24\%), and 2 with average inferior intelligence (6.06\%).

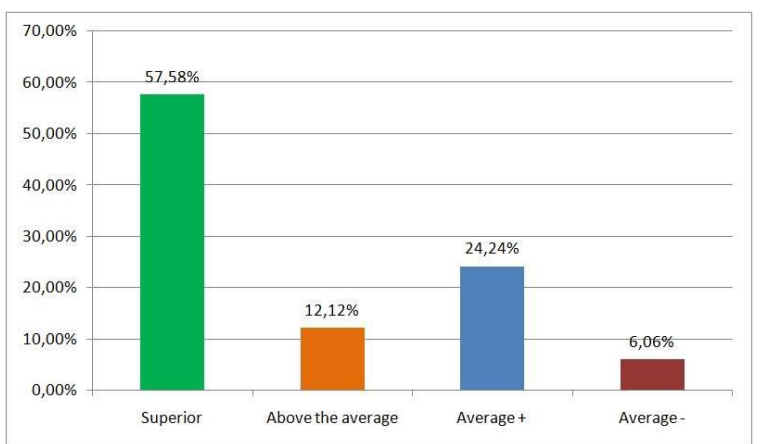

Figure 8. Level of general intelligence in the 8-year group $(\mathrm{N}=33)$

\section{Analysis based on the gender of the subjects}

Regarding the share of the type of laterality according to the gender of the subjects, it was found out that, from the total number of girls $(\mathrm{N}=$ 66), 43 were completely right-handed with stably accomplished laterality - RRR (65.15\%), 2 were completely left-handed with stably accomplished laterality - LLL (3.03\%), 15 girls had crossed ocular-manual and stably accomplished laterality RLR (22.73\%), 1 girl had homogeneous ocularmanual and stably accomplished laterality - LLR (1.51\%), 4 presented homogeneous ocular-manual and stably accomplished laterality - RRL (6.06\%), and 1 subject had LLR laterality (1.51\%) (Figure 9). 




Figure 9. Type of laterality in the girls'group $(\mathrm{N}=66)$

In the boys' group, from their total number $(\mathrm{N}=54)$ as it can be seen in Figure 10, 38 are with stably accomplished laterality defined by the RRR type (70.37\%), 2 with stably accomplished laterality defined by the LLL type (3.70\%), and 14 with crossed ocular-manual and stably accomplished laterality - RLR (25.93\%). No subject was identified with the following types of laterality: LRR, RRL, LLR.



Figure 10. Type of laterality in the boys' group $(\mathrm{N}=54)$

Regarding the level of general intelligence, 35 girls fall into the category of those with superior intelligence (53.03\%), 8 have above-average intelligence (12.12\%), 19 have average superior intelligence (28.78\%), and 4 have average inferior intelligence $(6.06 \%)$. The results are shown in Figure 11.



Figure 11. Level of general intelligence in the girls' group $(\mathrm{N}=66)$

In the boys' group the following results were registered (Figure 12): 30 boys with superior intelligence $(55.55 \%), 13$ with above-average intelligence $(24.07 \%), 8$ with average superior intelligence $(14.81 \%)$, and 3 with average inferior intelligence $(-)(5.55 \%)$.



Figure 12 Level of general intelligence in the boys' group $(\mathrm{N}=54)$

\section{Discussions}

The purpose of the study was to identify and analyse the type of laterality and level of general intelligence in children aged six, seven and eight years, respectively. The research hypothesis according to which 'the dominant laterality type and level of general intelligence manifests itself differently in 6-8 year olds who participate in physical education and sports classes' was supported by the results obtained by the subjects in the sample studied, which enabled the purpose of the research to be achieved. The analysis of the entire studied sample revealed that students completely right-handed with stably accomplished laterality (RRR) represent the majority . The next 
type of laterality is crossed ocular-manual and stably accomplished laterality (RLR), followed by completely left-handed with stably accomplished laterality (LLL) and by homogeneous ocularmanual and stably accomplished laterality (RRL). The least common types of laterality are crossed ocular-manual and stably accomplished laterality (LRR) and homogeneous ocular-manual and stably accomplished laterality (LLR).

According to the age based analysis, the same frequency of results is kept in terms of percentage of right-handed subjects and those with crossed ocular-manual and stably accomplished laterality; these types registering the highest percentage. It was also observed that the percentage of lefthanded children with complete stable laterality (LLL) is much lower than the other two types of laterality mentioned above.

The gender-based analysis supports the predominance of right-handedness (RRR) in both girls and boys; the second dominant type of laterality identified is once again the crossed ocular-manual and stably accomplished laterality (RLR).

The results obtained in the CPM Raven underline the fact that most of the subjects fall into the category of those with superior intelligence, followed by those with average-superior intelligence, then those with above average intelligence and those with average-inferior intelligence. The same order is maintained for the age groups. Differences were found after the analysis based on the gender of the subjects: for boys, the percentages related to intelligence levels are similar to those of the whole group, while for girls, superior intelligence represents the major category, followed by average-superior.

The results are similar to the statistics on the prevalence of the type of laterality, the most common type identified being that of right-handers [21]. The results are also consistent with those obtained by Tichy and Belacek, who found in a sample of 221 subjects aged between nine and eleven years that the dominant type of laterality is that of right-handed with completely accomplished laterality $(\mathrm{N}=166)$, the number of left-handed people with complete stable laterality being significantly lower $(\mathrm{N}=13)$, and the rest of the subjects $(\mathrm{N}=42)$ were classified as ambidextrous [22]. Also, Evangelista, Lopez, Jaramillo, Maruri, Quelal, Moncada, Guillen conclude that $70 \%$ of a sample of thirty subjects aged between seven and eight years are right-handed with stably accomplished laterality [23]. The significantly higher frequency of right-handers was also pointed out by Sitnikova, who also stated that the percentage of left-handed people was $8-12 \%$ of the entire population studied [24].

Regarding the level of intelligence, the results obtained in the present study coincide with those presented by Court and Mackintosch, who showed that the differences between genders in terms of level of general intelligence are not significant [25; 26 ; 27]. For the subjects participating in the present study, higher intelligence was identified as the dominant level in both the boys and girls groups. However, the differences appear in terms of the next level of intelligence frequency, girls presenting an average-superior intelligence, while in the group of boys superior intelligence is followed by the above the average intelligence. Gender differences related to the level of general intelligence were highlighted by Lynn and Irwing, as well as by Lynn, Alik and Must [28; 29]. MoşanuȘupac, Coşcodan, Liogchii also identified as the dominant level of intelligence in six- and sevenyear-olds, the high level intelligence also called the excellent intelligence, which was measured with the Goodenough Test [30].

\section{Conclusions}

Following the study, we can say that the hypothesis was supported by the results obtained. After applying the specific tests to determine lateral dominance and those to measure the level of general intelligence, we managed to establish them and their frequency among subjects in the sample studied.

Analyzing the results obtained, it was observed that in the case of subjects aged 6-8 years in the sample studied, the most common type of laterality was the completely right-handed with stably accomplished laterality, followed by the subjects with crossed ocular manual and stably accomplished laterality. A lower share than the two types of laterality mentioned above was detected 
among the ones that are completely left-handed with stably accomplished laterality. According to the results obtained by the subjects on the intelligence test, a preponderance of the superior level of intelligence can be observed, followed by above-average intelligence. No child recorded an intelligence level below the lower middle class. Determining the type of laterality and level of intelligence of the subjects that participate in physical education and sports classes is useful in order to effectively intervene on the psychomotricity components and to facilitate the process of adaptation of the child to the school environment. Specific and appropriate intervention on this component of psychomotricity is recommended through systematic exercise with the aim of developing and stabilising laterality, since the type of laterality is also involved in the learning and thinking style of the subjects and determines school performance, with benefits in all the disciplines studied.

\section{Conflict of interests}

There are no conflicts of interest associated with the methodology or results of this study.

\section{Acknowledgements}

The results presented in this paper are partly extracted from the author's doctoral thesis, which is ongoing at the Babeş-Boyai University in ClujNapoca, Doctoral School of Physical Education and Sports.

\section{References and websites}

1. Ghergut A. (2013). Sinteze de psihopedagogie specială. Ghid pentru concursuri și examene de obtinere a gradelor didactice. Editura Polirom, Iași, 170.

2. De Meur A., Staes L. (1985). Psychomotricite - education et reeducation, Ed. DeBoeck, Bruxelles, 121.

3. Albu C., Albu A., Vlad T. L., Iacob I. (2006). Psihomotricitatea. Metodologia educării și reeducării psihomotrice. Iaşi: Institutul European, 9, 35.

4. David S. J., Rajasankar S. (2016). Correlation between Handedness and Intelligence among School Children, International Journal of Contemporany Medical Research, 3 (9), 2683-2685.

5. Eysenck H. J., Arnold W., Wurzburg R.G., Meili B. (1972) Encyclopedia of Psychology, 2, London: Search Press, 182183.
6. Vrasmas E., Oprea V. (2003). Set de instrumente, probe și teste pentru evaluarea educatională a copiilor cu dizabilități. București: MarLink, 110.

7. García A., \& María C. (2017). La importancia de la lateralidad en el rendimiento escolar en educación primaria, 109-117.

8. Hellige J.B. (2001). Hemispheric Asymmetry: What's right and what's left. Cambridge: Harvard University Press, 63.

9. Sharma P. (2011). A study of learning-thinking style of secondary school students in relation to their academic achievement, International Journal on New Trends in Education and Their Implications, 2(4), 115-123.

10. Zlate M. (1999). Psihologia mecanismelor cognitive, Editur Polirom, Iași, 239- 465.

11. Golu M. (2007). Fundamentele Psihologiei Vol I. Editura Fundației de mâine, București, 812.

12. Volle M. et al. (1984). Required Physical Activity and Psychomotor Development of Primary School Children. In: Ilmarinen J., Välimäki I. (eds) Children and Sport. Springer, Berlin, Heidelbergp, 53-57.

13. Mas M., Jimanez L., Riera C. (2018). Systematization of the Psychomotor Activity and Cognitive Development, PsicologíaEducativa, 24(1), 38-41.

14. Moratal C., Huertas F., Boltá R. S.; Zahonero J., Lupiáñez J. (2008). Las habilidades sociales en relación con el perfil atencion al fútbol base. IV Congreso Internacional y XXV Nacional de Educación Física. Universidad de Córdoba, 112-128.

15. Hillmam Ch. H., Erickson K. I., Kramer A. F. (2008). Be smart, exercise your heart: Exercise effects on brain and cognition, Nature, 9, 58-65.

16. Meyer D.E., Kieras D.E. (1997). Computational Theory of Executive Cognitive Processes and Multiple-Task Performance: Part 2. Accounts of Psychological RefractoryPeriod Phenomena, Psychological Review, 104, 749-791.

17. Castelli D. M., Hillman Ch. H., Buck S. M., Erwin H. E. (2007). Physical Fitness and Academic Achievement in Third-and Fifth- Grade Students, Journal of Sport \& Exercise Psychology, 29, 239-252.

18. Murariu D., Gointa V. (2014). Influenţa motricităţii şi a psiho motricităţii asupra psihodinamici ineurocerebrale la copii şi adolescenţi, Psihologie, Revistă ştiinţifico-practică $1(2), 35-44$.

19. Vlad E. (2000). Evaluarea în actul educaţional-terapeutic, București: ProHumanitate, 144-146.

20. Raven C. J. (2005). Manualul testelor Matrici Progresive Raven şi al Scalelor de Vocabular: Formele Clasic şi Paralel. Matricile Progresive Raven Color. Secţiunea 2. Cluj: RTS (Romanian Psychological Testing Service), 7-29.

21. https://www.disabled-world.com/calculatorscharts/laterality.php, accesat în 28.05.2020.

22. Tichy J., Belacek J. (2008). Laterality in children: cerebellar dominance, handedness, footedness and hair whorl, Activitas Nervosa Superior Rediviva, 51(1-2), 9-20.

23. Evangelista D.S., Lopez N.G., Jaramillor D.D., Maruri C., Quelal J.A., Moncada R.P., Gillen K.E. (2017). Relationship Between Laterality and Motor Processes in Children Aged 78 Years with Malnutrition, Journal of Food Nutrition and Dietetics 03(01), 102. 
24. Sitnikova M. (2012). Educational peculiarities and difficulties of children with left-sided laterality: The technological solution of the problem, Cypriot Journal of Educational Sciences, 7(1), 14-24.

25. Court J. H. (1983). Sex differences in performance on Raven's Progressive Matrices: A review. Alberta Journal of Educational Research, 29, 54-74.

26. Mackintosh N. J. (1996). Sex differences and IQ. Journal of Biosocial Science, 28, 559-572.

27. Mackintosh N. J. (1998). Reply to Lynn. Journal of Biosocial Science, 30, 533-539.

28. Lynn R., Irwing, P. (2004). Sex differences on the progressive matrices: A meta-analysis, Intelligence, 32: 481-498.

29. Lynn R., Allik J., \& Must O. (2000). Sex differences in brain size, stature and intelligence in children and adolescents: Some evidence from Estonia. Personality and Individual Differences 29, 5.

30. Moşanu-Supac L., Coşcodan D., Liogchii N. (2012). Pregătirea către școală și adaptarea la procesul educaţional a copiilor de 6-7 ani prin prisma unor indici psihofiziologici, Stiinte ale Educatiei, (1), 70 - 78. 